\title{
ECOLINGUISTIC "WATER" IN TOBA BATAK LANGUAGE COMMUNITY
}

\author{
Tarida Alvina Simanjuntak ${ }^{1}$ \\ Universitas HKBP Nommensen \\ ridajuntak@yahoo.com
}

\begin{abstract}
Ecolinguistics is an interdisciplinary study that looks at the link between ecology and linguistics. This study involves other studies, including sociology, anthropology, psychology, and political science. Socioecological aspects also greatly affect the maintenance, balance, and environmental inheritance of future generations. These local ecological wisdoms need to be included in a healthy and green environmental discourse (green speak). Knowledge about natural entities for millennial generation has begun to decrease due to the influence of digital technology which is very large. This can also lead to environmental damage and can also damage language by not understanding the cultural functions of the ecolexicon. The amount of Eco lexicon shifting 'water' causes millennial generation to no longer know the use of these words in Toba Batak culture. Changes in the lifestyle of the Toba Batak millennial generation have changed considerably and pay less attention to the natural cultural functions. The method used in this study is observation, interviews and qualitative descriptive. This study describes the fact that many natural ecolexics are not recognized anymore and even almost extinct in the Batak Toba community (rootlessness), some of which are mabakbak (flowing tears), bibis (flowing from a container fullness, lungkis (flowing smoothly) and then elaborated in the discussion.
\end{abstract}

Keywords : Ecolinguistics 'Water', Toba Batak Language Society

\section{INTRODUCTION}

Ecolinguistics studies are interdisciplinary studies that look at the link between ecology and linguistics. In the discussion and its nature involves the study of sociology, anthropology, psychology. In addition to the social aspects, ecolinguistics considers the ecological aspects of the language spoken by speakers in a society. Socioecological aspects greatly affect the maintenance, balance, and environmental inheritance of future generations. Ecolinguistics or language ecology, seeks to create a healthy environment, by incorporating local ecological wisdom into the language. (Read Mühlhäusler 1995, Einar Haugen 1972, Palmer in Mbete 2009).

There are ten study rooms for language ecology namely comparative historical linguistics, demographic linguistics, sociolinguistics, dialinguistics, dialectology, philology, prescriptive linguistics, glotopolytics, ethnolinguistics, anthropological linguistics or cultural linguistics (cultural linguistics) typology. In other terms, this study is also known as the language ecology. There are actually four terms that refer to this study, namely linguistic ecology, ecological linguistics, the ecology of language / language ecology, and ecolinguistics.

In the Toba Batak language there is also a problem due to the displacement of the meaning of the natural elements used by the community in meeting the needs and preservation of language and culture. This shift in meaning means that the younger generation of the Toba Batak people no longer know the functions and uses of natural elements in the culture and customs of the Toba Batak people. This change is due to the lack of local cultural values communicated to the younger generation and the lack of young people's attention to the socioecoligical meaning of the natural surroundings. This can slowly make the culture extinct and the cultural terms will also disappear. As 
the next generation of languages, this study is certainly important. The natural elements discussed in this study are 'aek', 'ke-aek-an' and 'wateriness'. In Toba Batak culture, water has a very significant value. For example in the implementation of the Toba Batak traditional ceremony, water is one of the elements that must be presented. Water contains religious, social and ecological meanings. Especially in terms of human needs, almost everything needs water.

Some philosophies about water that are important in the life of a civilized society are;

\section{Water always flows from high to low}

The nature of water that always flows to a low place is analogous to a humble attitude in humans. Water always wants to be useful for the living creatures below. Like a leader, water is a leader who serves. If he is in the top position, then he will be a servant to people who need under him. Moreover, water is identical to the source of life. So it is not wrong if this first quality is analogous to the leader who serves. The leader who serves is a source of welfare for the community he leads.

\section{Water always fills empty spaces}

Good humans are people who try to fill the empty heart of other humans. By imitating the nature of water, humans should be able to be of help to other humans who are in trouble or in need.

\section{Water always flows into the estuary.}

No matter how far it is from the estuary, the water will definitely arrive there. Every human being must have a vision of life. The main thing that should be emulated from the water journey to the estuary is his consistent attitude.

\section{LITERATURE REVIEW}

To study the problem of the dynamics of the ecolexicon the use of ecolinguistic theory and assisted with structural linguistic theory to discuss the forms of lexicon of whims in BBT. Sapir (1912) argues that ecolinguistics is defined as the interaction between language and its environment through language speakers. This shows that because speakers of developing languages (new lexicons appear), persist (remain used of existing lexicon), shift (replacement of certain lexicons with other lexicons), or extinction (loss of certain lexicons). Gumperz's idea was later reinforced by Haugen (in Dil, 1972: 325-329) who said that the environment of a language is a speaker of language that can take the form of social and cultural settings.

This scientific discipline examines the interrelationship between language and the human / social environment and the natural environment. The term Ecolinguistics (language ecology) is related to the word 'ecology', which is the study of the interaction between organisms and their environment and others. In addition, the language through its lexicon also presents the physical environment, such as the environment of rain, water, mountains, rice fields, and so on.

The facts show that the natural environment changes, the language used by speakers also changes over time, as does the aesthetic lexicon of BBT.

\section{RESEARCH METHOD}

The method applied in providing data is the method of personal experience (Denzin and Lincoln, 1997: 573) where it is said that social science is focused on humans and patterns of relationships with others and their environment. Observation and interview techniques with native speakers were also conducted 
to obtain data. At the stage of analyzing the data used qualitative methods with descriptive-analytic techniques.

\section{RESULT AND DISCUSSION}

In the Batak Toba Language (BBT) 'aek' is interpreted as one of the important elements in the cultural order and

Table. 4.1. Verb Lexicon 'water' in Toba Batak Language

\begin{tabular}{|c|c|c|c|}
\hline No & Verba & BBT & BI \\
\hline \multirow[t]{16}{*}{1} & \multirow[t]{16}{*}{ Situation } & Nambur aris & Froze up \\
\hline & & Gurgur & Boiling \\
\hline & & $\begin{array}{l}\text { Margurakgu } \\
\text { rak }\end{array}$ & Rippling \\
\hline & & $\begin{array}{l}\text { Margalomb } \\
\text { ung }\end{array}$ & Bubbly \\
\hline & & Maruap & $\begin{array}{l}\text { Evaporate } \\
\text { (water) }\end{array}$ \\
\hline & & Nambur aris & Froze up \\
\hline & & Gurgur & Boiling \\
\hline & & $\begin{array}{l}\text { Margurak- } \\
\text { gurak }\end{array}$ & Rippling \\
\hline & & $\begin{array}{l}\text { Marjogo- } \\
\text { jogo }\end{array}$ & $\begin{array}{l}\text { Howling } \\
\text { (waterfall) }\end{array}$ \\
\hline & & $\begin{array}{l}\text { Marsidomd } \\
\text { om }\end{array}$ & $\begin{array}{l}\text { Rumble } \\
\text { (waterfall) }\end{array}$ \\
\hline & & $\begin{array}{l}\text { Gumalunsan } \\
\mathrm{g}\end{array}$ & $\begin{array}{l}\text { Surge (of } \\
\text { the sea) }\end{array}$ \\
\hline & & $\begin{array}{l}\text { Margalumba } \\
\text { ng }\end{array}$ & $\begin{array}{l}\text { Corrugated } \\
\text { (water) }\end{array}$ \\
\hline & & Maruap & $\begin{array}{l}\text { Evaporate } \\
\text { (water) }\end{array}$ \\
\hline & & Marabur ilu & $\begin{array}{l}\text { tears are } \\
\text { falling }\end{array}$ \\
\hline & & $\begin{array}{l}\text { Mangandun } \\
\mathrm{g}\end{array}$ & $\begin{array}{l}\text { Crying } \\
\text { while } \\
\text { speaking to } \\
\text { the corpse }\end{array}$ \\
\hline & & $\begin{array}{l}\text { Menganggu } \\
\text { hi }\end{array}$ & $\begin{array}{l}\text { Cry out } \\
\text { loud }\end{array}$ \\
\hline
\end{tabular}

Table. 4.2. Noun Lexicon 'water' in Toba Batak Language

\begin{tabular}{ccll}
\hline No & Jenis & \multicolumn{1}{c}{ BBT } & \multicolumn{1}{c}{ BI } \\
\hline \multirow{2}{*}{1} & Place & Binanga & $\begin{array}{l}\text { Collection of water } \\
\text { as in a small river }\end{array}$ \\
\cline { 3 - 3 } & & Sunge & River \\
\cline { 2 - 3 } & Aek laut & Sea water \\
\cline { 2 - 3 } & Tao & Lake \\
\cline { 2 - 3 } & Ambar & Small pool \\
\cline { 2 - 3 } & Lintong & Deep pool \\
\cline { 2 - 3 } & Hirta & Yellowish water in \\
\hline
\end{tabular}

customs. In ecolexicon studies (nouns, process verbs, and adjectives) the word water in BBT, there is a device or treasury of the lexicon which is almost unknown to the younger generation of the BBT community.

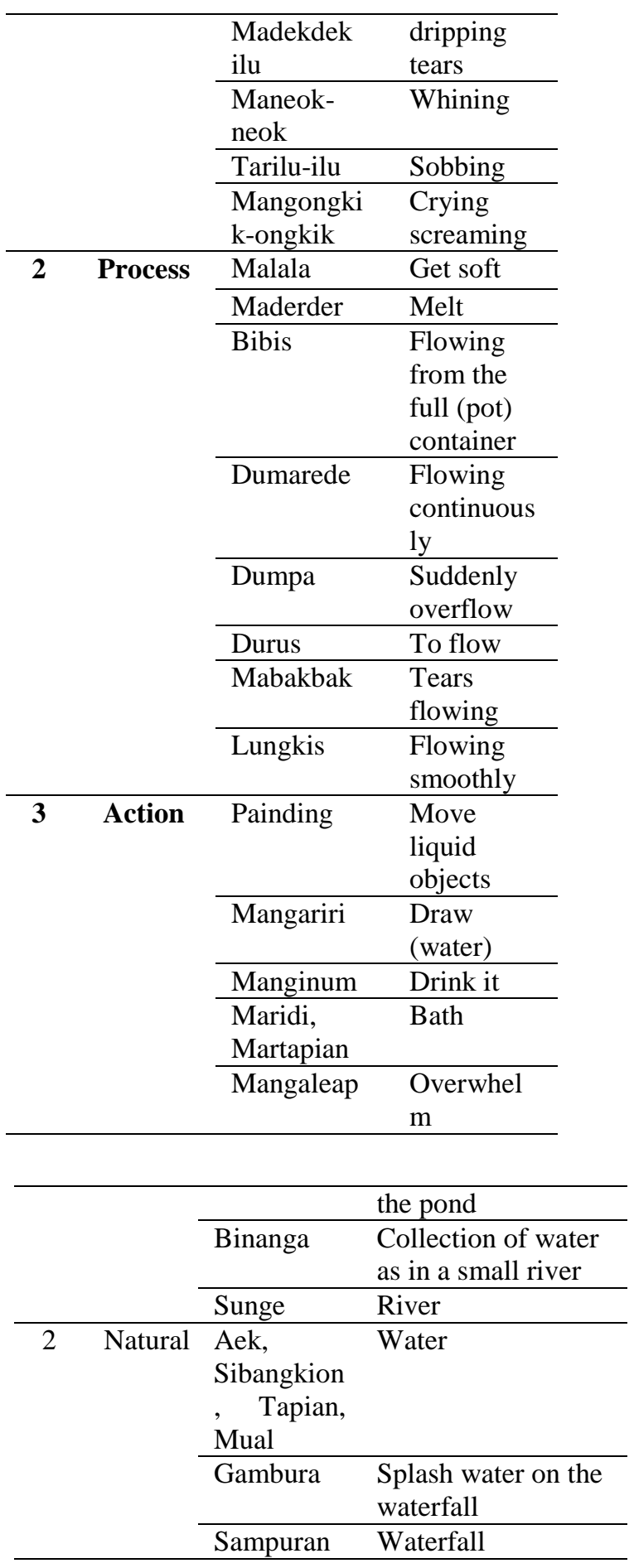




\begin{tabular}{|c|c|c|}
\hline & Mata mual & Water springs \\
\hline & $\begin{array}{l}\text { Aek } \\
\text { mirmir }\end{array}$ & Small spring \\
\hline & Aek gurgur & $\begin{array}{l}\text { Water overflowing } \\
\text { from the ground }\end{array}$ \\
\hline & $\begin{array}{l}\text { Aek } \\
\text { simatemate }\end{array}$ & $\begin{array}{l}\text { A spring that gives } \\
\text { water only once }\end{array}$ \\
\hline & $\begin{array}{l}\text { Aek } \\
\text { sipitudai }\end{array}$ & $\begin{array}{l}\text { Seven showers } \\
\text { from one spring } \\
\text { with seven flavors }\end{array}$ \\
\hline & Homban & Springs in the fields \\
\hline & Aek tabar & $\begin{array}{l}\text { Fresh water directly } \\
\text { from the forest }\end{array}$ \\
\hline & Mata mual & Water springs \\
\hline & $\begin{array}{l}\text { Aek } \\
\text { sitiotio }\end{array}$ & $\begin{array}{l}\text { Water is served to } \\
\text { guests }\end{array}$ \\
\hline & $\begin{array}{l}\text { Sahit } \\
\text { tungkihon }\end{array}$ & $\begin{array}{l}\text { Disease ear issued } \\
\text { smelling fluid }\end{array}$ \\
\hline & Dane & $\begin{array}{l}\text { The liquid that } \\
\text { comes out from a } \\
\text { decomposed corpse }\end{array}$ \\
\hline & Aek rangat & Warm water \\
\hline & Aek udan & Rainwater \\
\hline & Sampean & $\begin{array}{l}\text { Spring under the } \\
\text { mountain }\end{array}$ \\
\hline & Sonop & Flood \\
\hline & Arimojan & Tears broke down \\
\hline & Ilu & Tears \\
\hline & Honsing & Urine \\
\hline \multirow[t]{6}{*}{ Artificial } & Gas andalu & $\begin{array}{l}\text { Strong water turned } \\
\text { the wheel }\end{array}$ \\
\hline & Pamispisan & $\begin{array}{l}\text { Place of water } \\
\text { falling from the } \\
\text { roof }\end{array}$ \\
\hline & Panirisan & $\begin{array}{l}\text { Water drainage } \\
\text { place }\end{array}$ \\
\hline & Aek dali & Milk \\
\hline & Inumon & Drinks \\
\hline & Borsi & Liquor \\
\hline \multirow[t]{2}{*}{ Tool } & $\begin{array}{l}\text { Garung- } \\
\text { garung }\end{array}$ & $\begin{array}{l}\text { Bamboo jugs for } \\
\text { storing liquid } \\
\text { objects }\end{array}$ \\
\hline & $\begin{array}{l}\text { Ansung- } \\
\text { ansung }\end{array}$ & $\begin{array}{l}\text { The dose of } \\
\text { bamboo used for } \\
\text { liquid }\end{array}$ \\
\hline \multirow[t]{3}{*}{ Volume } & $\begin{array}{l}\text { Lobi-lobi, } \\
\text { Jaean }\end{array}$ & Wastewater \\
\hline & Aek tabar & Freshwater \\
\hline & Aek tio & Clear water \\
\hline
\end{tabular}

\begin{tabular}{cll}
\hline 4. & Borgo & Cool \\
\hline 5. & Rangat, Lamo & Warm \\
\hline 6. & Ngali & Cold \\
\hline 7. & Mermer & Fresh \\
\hline 8. & Habut & Cloudy \\
\hline 9. & Lango & Bid \\
\hline & The use of vocabulary that
\end{tabular}
originates from water is rarely used even endangered because it is not fully used in daily life and is less known by the people. This causes language extinction slowly. As explained above, language will change as soon as the ecology that supports it changes. So from the variety of languages undergoing changes in their ecology, some of the terms will no longer be commonly used by speakers. This vocabulary may become extinct as a result of not being heard often.

From the description of the ecolexicon, the quality of the human relationship with water is very close (deep ecological relationship). There are more or less 35 verbs of necromancy in BBT, which shows that there are many human activities related to water in daily life. It can also be seen that there are approximately 42 no-nonsense names in BBT, this shows the close relationship between humans and things or objects related to water. The data above shows the specific naming of each object to distinguish its use. As for the adjective adjectives there are about 9 adjectives. This shows that the character of 'aek' is quite limited according to the definitions of the BBT community.

In addition to ecolexicon studies, in this discussion it also examines socioecological meanings found in water in BBT. This can be seen that there are changes in water treatment in the community today.

Table. 4.3. Adjective Lexicon 'water' in Toba Batak Language

\begin{tabular}{cll}
\hline No. & \multicolumn{1}{c}{ BBT } & \multicolumn{1}{c}{ BI } \\
\hline 1. & Maderder & Liquid \\
\hline 2. & Litok & Dirty \\
\hline 3. & Gurgur & Rippling \\
\hline
\end{tabular}

1. Mangariri (draw), then become using a water pumping machine.

This scavenging activity is rarely found in community settlement areas at this time, this is because the community, 
including in rural areas, have also used pump machines to save energy and reduce risks in water.

2. Mangalompa aek (boiling water), it becomes a dispenser.

This activity is no longer an important activity in daily life. This was replaced by the existence of a tool that is able to process water to become hot and cold with the help of electricity.

Examples of changes above illustrate the shift in meaning of water treatment in life in society. In BBT culture the use of water in traditional ceremonies and the traditions of the people is still very important. But the meaning of this matter is also not understood by many young people today.

\section{Parhombanan}

Human development requires an organized arrangement of life. The arrangement of life is regulated by the arrangement of the environment of the house or village, source of life, health and social relations. It is better if the selection of a settlement, the main indicator is the presence of water sources, the sub-indicator is the ease of access to the water source. Selected water sources are rivers, showers and springs. The water source is then flowed into the rice fields, as the main source of drinking water and the ritual needs of the "Pangurason".

Once a year a ritual event at the spring is called "mangase homban" which aims to take care by cleaning up the location of the spring, caring for plants and trees around it, maintaining downstream water flow to repairing the rice field. This is the first sign of going down to the field after one year of being used for a source of life and starting a new activity for a new life in the future.

\section{Pangurason}

Water in this case is used in the rituals of the Toba Batak tradition which is believed to cleanse the spirit and soul of someone who is being disturbed by an evil spirit. The treatment is to bathe the person or simply by feeding water on his face (manguration).

\section{Martutuaek}

In the Batak people's belief, water is the beginning of physical life. Martutuaek means to go to a water source, which is meant to introduce a newborn human to water which is the priority of a source of life before recognizing all that is on earth.

\section{Panguhatan}

Water sources in the house are in the form of earthen pots, and now many have been replaced with buckets

\section{Pandidion}

Water is used in religious rituals, intended as a symbol used by the Pastor to bless the newborn child and the ceremony of child surrender in the church. In this case the method used by rubbing water on the child's head.

\section{CONCLUSION}

The language through its lexicon also presents the physical environment, such as the environment of rain, water, mountains, rice fields, and so on.

The facts show that the natural environment changes, the language used by speakers also changes over time, as does the aesthetic lexicon of BBT.

\section{REFERENCES}

Chaer, Abdul. 1995. Pengantar Semantik Bahasa Indonesia. Jakarta: PT. Renika Cipta. 2012. Linguistik Umum. Jakarta: Renika Cipta. 
Denzin, Norman K dan Lincoln, Yvonna, Norman K. 2009. Handbook of Qualitative Research: Edisi Bahasa Indonesia. Yogyakarta: Pustaka Pelajar.

Fill, A. Dan P. Muhlhausler (ed,). 1995. The Ecolinguistics Reader: Language Ecology and Environment. London: Continuun.

Haugen, E. 1972. "The Ecology of Language”, in Dil, A. S. (ed.) The Ecology of Language: Essays by Einar Haugen, Stanford: Stanford University Press.

Kridalaksana, Harimurti. 1996. Pembentukan Kata dalam Bahasa Indonesia. (edisi kedua). Jakarta: PT Gramedia Pustaka Utama.

Mbete, A. M. dkk. 2009. Penyusunan Sosio ekologi Bahasa Melayu Langkat dan Bahasa Muna serta Upaya Pemberdayaannya. Laporan Penelitian. Denpasar: Universita Udayana.

Sapir, Edward. 1912. Language and Environtment,

American
Anthropologist. Volume 14, page 226-242. American Anthropological Association.

Sarmi, Ni Nyoman. 2015. Khazanah Leksikon Lingkungan Alam dalam Dinamika Guyub Tutur Bahasa Using: Kajian Ekolinguistik." Denpasar: Doertasi Untuk Universitas Udayana.

Saussure, Ferdinand de. 1988. Pengantar Linguistik Umum. Terjemahan. Jogyakarta: Gajah Mada University Press, 1993, hlm. 23 dan 374-378.

Sudaryanto. 1988. Metode Linguistik Bagian Kedua: Metode dan Teknik. 1976. Pengumpulan Data. Yogyakarta: Gajah Mada University Press.

Sudaryanto. 1993. Metode dan Aneka Teknik Analisis Bahasa Pengantar Penelitian Wahana Kebudayaan. Yogyakarta; Duta Wacana University Press.

Verhaar, J.W.M. 2012. Asas-asas Linguistik Umum. Yogyakarta: Gajah Mada University Press. 